\title{
THE UNRECOGNIZED GOVERNMENT IN AMERICAN COURTS: UPRIGHT V. MERCURY BUSINESS MACHINES
}

\author{
STANLEY LUBMAN*
}

\begin{abstract}
What right have I, as the King's Judge, to interfere upon the subject of a contract with a country which he does not recognize ? ${ }^{1}$
\end{abstract}

Lord Eldon's words, written in 1823, have been echoed more than once by American judges, who have been as troubled as Eldon by problems complicated by diplomatic nonrecognition. Twentieth-century wars and revolutions have required American courts to decide whether unrecognized governments, entities created by them, their representatives, or their assignees could sue in domestic courts, often on matters of private right. ${ }^{2}$ Frequently, too, the courts have been perplexed by the effect of nonrecognition on the application of foreign laws and decrees.

Uncertain of the consequences that should flow from nonrecognition, the courts have often responded as Eldon did; alarmed by the suggestion that their "recognition" of a government might conflict with executive nonrecognition, they have frequently endeavored to treat unrecognized governments" as nonexistent. In addition, the courts have often emulated Lord Eldon, in their own fashion, by hastily deferring to supposedly overriding considerations of foreign policy as expressed, at times, by the State Department. Only rarely have they evaluated in a sophisticated manner the basis in policy and precedent for taking judicial cognizance, in any context, of an unrecognized government.

As long as trade and other contacts with unrecognized countries are not prohibited, ${ }^{3}$ these questions of doctrine and judicial technique will be presented to the courts. They have most recently been raised and provocatively discussed by the Appellate Division of the Supreme Court of New York in Upright v. Mercury Business Machs. Co.4 To some extent Upright is a wel-

* Member of the New York Bar. The author acknowledges with appreciation the helpful suggestions of Allan Blumstein, Esq., of the New York Bar.

1. Jones v. Garcia del Rio, 1 Turn. \& Rus. 297, 299, 37 Eng. Rep. 1113, 1114 (ICh. 1823) (opinion of Lord Eldon). The early influence of Lord Eldon on the attitudes of English courts toward unrecognized governinents is discussed in BusheFox, The Court of Chancery and Recognition 1804-31, 12 BRIT. YB. INT'L L. 62 (1931). See also Bushe-Fox, Unrecognized States: Cases in the Admiralty and Common Law Courts 1805-26, 13 BRIT. YB. INT'I L. 39 (1932).

2. The terms "government" and "state" are used synonymously in this article. The term "private right" is specifically intended to include rights that a government could assert against a nongovernmental entity or a person with whom it entered into a commercial transaction.

3. Trade is affirmatively prohibited only with China and North Korea. See 131 C.F.R. $\$ \S 500.204$ (Supp. 1961).

4. 13 App. Div. 2d 36, 213 N.Y.S.2d 417 (1st Dep't 1961), reversing 26 Misc. $2 \dot{\mathrm{d}}$ 1069,207 N.Y.S.2d 85 (Sup. Ct. 1960). No appeal was taken froin the decision. 
come departure from past decisions; in other respects it bears an unfortunate resemblance to them. This article will discuss Upright and some of its implications and contradictions, with the hope of contributing to a clarification of some of the problems that nonrecognition has persistently created for American courts and will consider a method that the courts may use in meeting those problems.

\section{The Upright Decision}

\section{A. The Trial Court}

Plaintiff, an American citizen and resident of New York, sued in the Supreme Court, New York County, as the assignee for value after maturity of a trade acceptance drawn on and accepted by defendant, a New York corporation. The acceptance represented an obligation to pay for typewriters sold and delivered to defendant by the drawer-assignor, Polygraph Export GmbH. Defendant's counsel had been advised by a cablegram ${ }^{6}$ from the Chief of the Economic Affairs Section of the United States Mission to West Berlin that Polygraph was a "state-controlled enterprise of the so-called German Democratic Republic (GDR)."

Defendant answered ${ }^{8}$ that plaintiff lacked capacity to sue, alleging that

5. Brief for Appellant, p. 5, id.

6. Counsel for defendant had cabled the following request:

USBER BLN TELAUFN BLN S1 LT; Commercial Attache US Consulate General West Berlin would appreciate your cabling collect following information is polygraph export $\mathrm{GmbH}$ a corporation organized and existing under laws of republic of West Berlin or is it East German corporation stop is its principal place of business freidrichstr 61 Berlin and is this in West Berlin or East Berlin stop If an East corporation is it registered or qualified to do business in West Germany and if so please advise date of registration and business address in West Germany or West Berlin: LANTALAW.

Brief for Appellant, pp. 3-4, id.

7. The response states in full:

From U.S. MISSION BERLIN to: THE DEPARTMENT OF STATE (for Commerce) Ref: Telegram from LANTALAW, New York, dated December 18, 1958 Subject: Polygraph Export GmbH, 61 Friedrichstrasse,

* *Berlin W 8

This office received the attached telegram concerning information on subjeet firm.

Polygraph GmbH is situated in the Soyiet Sector of Berlin and is a state controlled enterprise of the so-called German Democratic Republic (GDR). Its main office is in East Berlin. Firms of this kind have no branehes in West Germany or West Berlin and are sometimes engaged in business transactions with businessmen in the Western area who do not have the best reputation. Since this Mission is not able to send collect cables, this matter is forwarded to the Department of Commerce for whateyer action the Department may deem appropriate.

Brief for Appellant, pp. 5-6, id.

8. Defendant had first moved to dismiss the complaint on the ground that plaintiff lacked capacity to sue. After a reference was ordered by Justice Aurelio to determine - the issue of Polygraph's state of incorporation, plaintiff conceded that his assignor was an East German corporation. Beeause there was no evidence supporting defendant's contention that Polygraph was an "instrnmentality" of the East German government, Justice Aurelio refused to dismiss the complaint, but gave leave to defendant to raise i its objection as an affirmative defense. Upright v. Mercury Business Machs. Co., 24 Misc. 2d 571, 203 N.Y.S.2d 288 (Sup. Ct. 1960). Justice'Aurelio's opinion states in part: 
the German Democratic Republic was not recognized by the United States and that plaintiff's assignor, organized under the laws of that country, was "an instrumentality or arm" of its government and as such could not maintain suit. The assignee of such an entity, contended the defendant, has no greater right to maintain the action ${ }^{9}$ than his assignor.

Justice Streit, sitting in Special Term, held that the defense was valid.10 He disregarded the alleged corporate nature of the plaintiff's assignor, and deemed the question presented to be whether the assignee of an unrecognized government could sue. It was clear to Justice Streit that the New York Court of Appeals decision in Russian Socialist Federated Soviet Republic v. Cibrario ${ }^{11}$ established that an unrecognized government could not sue. In that case, the then unrecognized Soviet government had brought an action to compel an accounting from an allegedly dishonest purchasing agent, and the court dismissed the complaint on the ground that public policy required that the plaintiff be denied access to our courts. It was asserted that

to hold otherwise might tend to nullify the rule that public policy must always prevail over comity. ... To permit ... [plaintiff] to recover in our courts funds which might strengthen it or which might even be used against our interests would be unwise. We should do nothing to thwart the policy which the United States had adopted. ${ }^{12}$

Justice Streit quoted these words and relied heavily on them. It was clear to him that Cibrario should be extended to bar access to the New York courts by the assignee of an unrecognized government, whether or not the

\footnotetext{
Upon ... [plaintiff's] concession the court cannot recognize the existence of a juridical creature of a government we do not recognize. The court will take judicial notice that the German Democratic Republic is not recognized by our Government. However, even though plaintiff's assignor would have no right to sue in this court as a corporation since the recognition of that legal entity is barred by the foreign policy of the United States Government, nevertheless it cannot be denied that some organization or group of persons does exist and entered into a commercial transaction with the defendant. If it were clear that this group of people consisted of private citizens unconnected with the unrecognized government, the court is of the opinion that no further question would exist. The foreign policy of the United States Government does not require us to deny that there are people residing in and doing business in a certain geographical area. No prohibition or restriction seems to have been imposed on trading in the items which are the basis of this cause of action. Where, as here, it has received the benefits of the commercial transaction, it would be inequitable to permit defendant to retain the fruits thereof without compensation .... .

However, overriding foreign policy considerations may make necessary a denial of access to our courts in the event it is determined that the defendant dealt in some form with the unrecognized Government of the German Democratic Republic.
}

Id. at $572-73,203$ N.Y.S.2d at $289-90$.

9. Record on Appeal, pp. 10-11, Upright v. Mercury Business Machs. Co., 13 App. Div. 2d 36, 213 N.Y.S.2d 417 (1st Dep't 1961).

10. Upright v. Mercury Business Machs. Co., 26 Misc. 2d .1069, 207 N.Y.S.2d 85

(Sup. Ct. 1960).

11. 235 N.Y. 255,139 N.E. 259 (1923).

12. Id. at 263,139 N.E. at 262 . 
assignee was obligated to remit the proceeds of the assigned claims to his assignor. If remittance were to follow recovery, then the unrecognized government would be directly strengthened; if there were no remittance, the unrecognized government could nevertheless obtain financial strength by selling its claims against our citizens. ${ }^{13}$

The plaintiff, then, could have "no greater right to sue than his assignor." 14 Decisions permitting assignees to sue even though their assignors could not have sued were distinguishable, in Justice Streit's view, because they "do not involve a question of an assignment void as against public policy, such as that here presented."15 The quotation from Cibrario was the only indication that the policy presumably violated was the policy forbidding suit by unrecognized governments. Thus, without considering whether the underlying transaction with the unrecognized government violated public policy, the lower court ruled that the assignment of a debt created by the transaction affirmatively violated public policy and barred an American plaintiff from suing on the obligation.

\section{B. The Appellate Division}

The appellate division reversed, holding that the defense that plaintiff was incapable of bringing suit, based as it was solely on the fact of nonrecognition, was insufficient.

Justice Breitel, writing for the court, ruled that the "political" decision not to recognize a government does not deprive it of a "juridically cognizable" de facto existence. ${ }^{16}$ The courts are not precluded by nonrecognition from considering the effect on private rights of the acts and laws of such a government, effects that nonrecognition plainly could not prevent; nonrecognition does not affect the capacity of the unrecognized government, its entities, and persons living within its territory to trade and to contract. ${ }^{17}$

Because nonrecognition of itself neither prevents private transactions nor bars the courts from considering them, such transactions, including the one in Upright, are unenforceable only if they violate a definite public policy. ${ }^{18}$ The defendant, however, had not alleged that its transaction with the East German corporation or the assignment to Upright of the trade acceptance was illegal or violative of public policy. Indeed, during the argument of the case before the appellate division, it was stated without contradiction that the typewriters had been "slipped openly and passed regnilarly through United States Customs."19 Defendant was obviously "hard put" to find a policy that forbade

13. 26 Misc. $2 \mathrm{~d}$ at 1069,207 N.Y.S.2d at 86 .

14. Id. at 1070,207 N.Y.S.2d at 86.

15. Ibid.

16. 13 App. Div. 2d at. 38, 213 N.Y.S.2d at 419.

17. See text accompanying notes 105-09 infra.

18. See text accompanying notes 108-13 infra.

19. 13 App. Div. 2d at 37, 213 N.Y.S.2d at 419 (footnote of the court). 
suit or recovery against him if the transaction was both permitted and "facilitated" by the federal government; without alleging such a policy, however, he could not prevail. ${ }^{20}$ Justice Steuer concurred in the result only, apparently on the ground that defendant had failed to allege sufficiently that the assignment to plaintiff violated public policy. ${ }^{21}$

Although Justice Breitel did not question the rule that an unrecognized government can not sue, he did suggest in dictum that the principles summarized above would permit a corporation created by an unrecognized government to bring suit. But the issue of whether suit could be maintained by an entity created by an unrecognized government was not presented in $U p$ right, and when it was before the court it was to be resolved by reference to "actual facts," which should be given effect unless to do so would violate public policy. ${ }^{22}$

In some respects, Justice Breitel's opinion is a welcome expression of judicial realism in an area in which judicial realism has not been conspicuous. His opinion marks an attempt to choose as an instrument for decision, in cases involving the effect of nonrecognition on private rights, the principle that Professor Jaffe has called the "de facto" principle. ${ }^{23}$ In nonrecognition cases this principle allows the courts to take direct cognizance of the existence of governments that in fact exercise control over the areas they purport to govern, unless public policy would clearly be violated by applying the laws and decrees of such a government, or, in some situations, by permitting it to sue in American courts. If Upright represents an attempt to implement the de facto principle in matters of private right, that attempt was made in preference to a less definite approach to nonrecognition that, often coupled with a questionable reliance on State Department pronouncements, has far more often been taken by American courts. In these matters, Lord Eldon has had a large following.

Yet Justice Breitel's opinion is not free from emphasis on concepts alien

20. Id. at 42,213 N.Y.S.21 at 423. See text accompanying note 110 infra.

21. Id. at 42,213 N.Y.S.2d at 424 .

22. Id. at 40,213 N.Y.S.2d at 422 .

23. Jaffe, Judicial Aspects of Foreign Relations 168 (1933). Professor Jaffe's discussions of the de facto principle and of nonrecognition generally have been of great assistance in preparing this article.

Compare the meaning of the term de facto as used in this article with the Re-

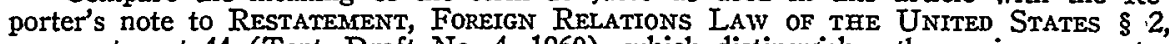
comment $c$ at 44 (Tent. Draft No. 4, 1960), which distinguishes the various connotations that the term de facto has been given. In diplomatic parlance, it has been used to characterize the following: a tentative diplomatic recognition that can be withdrawn; a policy that permits recognition of a government although it "came mto power in violation of the constitution of the state"; and the policy of recognition in which actual control of the state is the essential precondition to recognition and the ability and intention of the regime to fulfill the state's international obligations is not an additional requirement. In addition, however, the Reporter notes that the courts have used the term "in dealing with the effect to be given the acts of non-recognized regimes which are in actual control of the state." The term de facto was not employed by the court in Upright, nor has it been in this article, to signify any of the extra-judicial, political, or diplomatic mearings enumerated above. 
to a realistic approach to nonrecognition. The conflict with the de facto principle that is created by relying on these concepts requires analysis. This article, accordingly, will discuss the varying judicial reactions to the problem created by nonrecognition, among them the complementary role of executive and judiciary, as they have been expressed in earlier decisions and by the court in $U$ pright. In addition, $U$ pright deals directly enough with the problems of the unrecognized government as plaintiff to provoke a reexamination of the rule that such a government may not sue, as well as a consideration of the manipulation of the rule in Upright. Finally, because $U_{p-}$ right evidences contrasting methods of decision in nonrecognition cases, it is appropriate to consider the relevance of these methods to the problem of the unrecognized government as plaintiff.

\section{Traditional Law}

Early in his opinion, Justice Breitel stated:

A foreign government, although not recognized by the political arm of the United States Government, may nevertheless have de facto existence which is juridically cognizable. The acts of such a de facto government may affect private rights and obligations arising either as a result of activity in, or with persons or corporations within, the territory controlled by such de facto government. This is traditional law.24

Actually, the "traditional law" declared by Justice Breitel differs significantly from that of prior decisions. Many courts other than that of Lord Eldon have taken "juridical cognizance" of unrecognized governments only in an unwilling and incoherent manner. Indeed, traditional law is better reflected in the proposition that American courts will not give effect to the acts of unrecognized governments unless it is clear to them that to do otherwise would be manifestly absurd. ${ }^{25}$ This is not to say that Justice Breitel's statement is in error; rather, it is the product of a skillful interpretation of the available and conflicting precedents, which drew forth from them a recognizably more positive doctrine. It is thus essential to examine the cases to which Justice Breitel looked to determine the content of traditional law.

The cases in which nonrecognition has created problems have usually been far more difficult to decide than Upright. They have most often involved the issue of the effect that should be given to the confiscatory acts of unrecognized governments created in war or revolution, and, less frequently, whether suit could be brought by such governments. The best known cases

24. 13 App. Div. $2 d$ at 38,213 N.Y.S.2d at 419.

25. Compare 51 ColuMr. L. REv. 531 (1951): "non-recognized governments aro denied even the privilege of suing in the courts of the forum and their official acts have no standing in such courts, except in private litigation where justice requires they be given effect, and provided there is no serious conflict with executive poliey." 
were decided by American courts attempting to cope with some of the consequences of the Russian Revolution, and another well known group of cases are the federal decisions involving the extraterritorial effect of the confiscatory decrees of the Soviet-annexed Baltic republics. While these decisions have been extensively discussed and analyzed elsewhere, ${ }^{26}$ it is instructive to review briefly some of the more important ones for the purpose of determining the content of traditional law.

\section{A. The Russian Revolution in the Courts}

1. The Soviet government as a party to suit. In Wulfsohn v. Russian Socialist Federated Soviet Republic, ${ }^{27}$ the New York Court of Appeals held that the Soviet government, although unrecognized, was entitled to sovereign immunity from suit for conversion of property confiscated by the Soviets in Russia. The plaintiff admitted and the court did not question that the Soviet government was the "existing de facto government of Russia."28 The Soviet government, like other sovereigns, could not be sued without its consent, ${ }^{29}$ and it had not consented; moreover, to permit suit might embarrass the conduct of foreign affairs by the State Department. In the Cibrario ${ }^{30}$ decision, however, the court held that public policy required that the unrecognized government be barred from suing in this country.

26. Some of the discussions of the post-Russian Revolution decisions include: JAFFE, op. cit. supra note 23, at 140-98; Borchard, The Unrecognized Government in American Courts, 26 AMr. J. INT'L L. 261 (1932) ; Connick, The Effect of Soviet Decrees i) American Courts, 34 Y ALE L.J. 499 (1925); Dickinson, Recognition Cases, 19251930, 25 AM. J. INT' I. 214 (1931) ; Dickinson, Recent Recognition Cases, 19 AM. J. INT'L L. 263 (1925); Dickinson, The Unrecognized Government or State in English and American Law, 22 MrcH. L. Rev. 29, 121, 134 (1923); Nebolsine, The Recovery of the Foreign Assets of Nationalized Russian Corporations, 39 YALE L.J. 1130 (1930); Tennant, Recognition Cases in American Courts, 1923-1930, 29 MICH. L. REv. 708 (1931); Untermyer, Judicial Interpretation of the Soviet Decrees in Relation to Private Rights, 1 GEo. WASH. L. REv. 471 (1933) ; Comment, Can an Unrecognized Govermment Stle?, 31 YAle L.J. 534 (1922).

Some of the discussions of the "Baltic ship" cases include: Briggs, Non-Recognition in the Conts: The Ships of the Baltic Reprublics, 37 AM. J. INT'L L. 585 (1943); 58 HARV. L. REv. 612 (1945).

This article is concerned oniy with American law. For one of the many discussions of English and continental judicial attitudes toward unrecognized governments, particularly that of Soviet Russia, see LAUTERPACHT, RECOGNITION IN INTERNATIONAL LAw 145-57 (1948).

27. 234 N.Y. 372, 138 N.E. 24 (1923), appeal dismissed, 266 U.S. 580 (1924).

28. Id. at $374,138 \mathrm{~N}$.E. at 25 .

29. But see Hennenlotter v. Norwich Union Fire Ins. Soc'y, 207 N.Y. Supp. 588 (Sup. Ct. 1924), in which the court, on plaintiff's motion, ordered that service of process be made on a Russian corporation as an additional party defendant. The Soviet government had evidently attempted to nationalize the corporation, whose officers were apparently located in Moscow, and the defendant claimed that the corporation "is now an arm or part of the Soviet government of Russia, and that, since our government has refused to recognize the Soviet government of Russia it is impossible to make it a party." Ibid. The court, however, rejected this argument by stating, "the Russian corporation is to be regarded, not as an agent or instrumentality of the Soviet government, but as still being the pre-Soviet corporation, unaffected by the acts or decrees of the present government of Russia, and qualified to act, be sued, or appear as it existed prior to the revolution." Ibid.

30. 235 N.Y. at 255, 139 N.E. at 259. This case is discussed in text accompanying notes 115-22 infra. 
The federal courts have similarly barred the Soviets from maintaining suit. Repeatedly called upon to decide whether the unrecognized Soviets could be deemed the successors to the nonexistent Provisional government, which nevertheless remained for a long period of time the only Russian government recognized by this country, the federal courts refused to allow the Soviet government to sue in its own name; ${ }^{31}$ conversely, representatives of the Kerensky government were permitted to sue as the representatives of the "State of Russia,"32 and an assignee of the Kerensky government was permitted to sue as the successor in interest of an obligation originally owed to the Czarist government. ${ }^{33}$

2. The effect of confiscatory decrees. In neither Wulfsohn nor Cibrario was the New York Court of Appeals required to consider the effect that should be given to Soviet decrees or laws, or whether Soviet acts were to be regarded as law. When it encountered, or created these problems for itself, the court spoke in several and often contradictory tongues.

Sokoloff v. National City Bank $k^{34}$ embodies the conflicting tendencies. Judge Cardozo stated in that decision that because of "common sense and fairness" unrecognized governments could not inflexibly be regarded as nonexistent. $^{35}$ Yet, in the same opinion, he also suggested that the acts of the

31. The Penza, 277 Fed. 91 (E.D.N.Y. 1921); The Rogdai, 278 Fed. 294 (N.D. Cal. 1920).

32. Russian Gov't v. Iehigh Valley R.R., 293 Fed. 135 (S.D.N.Y. 1923), aff'd, 21 F.2d 396 (2d Cir.), cert. denied, 275 U.S. 571 (1927); The Rogdai, supra note 31.

33. Agency of Can. Car \& Foundry Co. v. American Can Co., 253 Fed. 152 (S.D.N.Y. 1918), aff'd, 258 Fed. 363 (2d Cir. 1919). Cf. Russian Volunteer Fleet v. United States, 282 U.S. 481 (1931), in which the plaintiff was allowed to recover compensation for the seizure of ships by the United States during the First World War. The Court of Claims had held that because the U.S.S.R. was not recognized, the plaintiff could not sue because of what is now 28 U.S.C. \& 2502 (1958), which then provided that aliens of "any government" could not prosecute claims against the United States unless that "government" reciprocated by allowing American citizens to prosccute claims against it. The court took the view that "any government" applied only to recognized governments. On appeal, the United States submitted its case on the Court of Claims opimion, although apparently it also took the position that the statute requiring reciprocity as a condition of the alien's right to sue did not apply to the special wartime statute under which the ships had been requisitioned and the suit brought. The United States did submit with its brief a letter from the Secretary of State indicating that this country had recognized no government of Russia after the overthrow of the Provisional government.

The Supreme Court stated: "As the facts alleged in the petition were admitted by the motion to dismiss, the allegation that the petitioner is a corporation duly organized under the laws of Russia stands unchallenged on the record." 282 U.S. at 489 . The objection to the plaintiff's capacity thus minimized, the Court proceeded to assert that as an "alien friend" the plaintiff was entitled to the protection of the fifth amendinent. The United States could not escape its obligation to pay just compensation for expropriated property and Congress had not intended to allow the right to reccive compensation to be defeated either because American citizens allegedly could not prosecute claims to Russia against the government of that country or because the government was unrecognized: "the right to compensation ... sprang into existence at the time of the taking. ... The question as presented here is not one of a claim advanced by or on behalf of a foreign government or régime, but is simply one of compensating an owner of property taken by the Umited States." Id. at 492.

34. 239 N.Y. 158, 145 N.E. 917 (1924).

35. The opinion states:

Juridically, a government that is unrecognized may be viewed as no 
unrecognized Soviet government were not law, and that the Soviet government was not a government. The plaintiff had sued for restitution of a sum of money that he had deposited in New York upon a promise to pay rubles in Petrograd. Confiscation of the assets of the defendant's Petrograd branch was pleaded as a defense and rejected by the court because the nationalization decrees were not those of a de jure government and because they had not affected the existence of the defendant, an American corporation. The decision may have been correct, as it was supported by the fact that the defendant had not been entrusted with a specific res and the plaintiff had not contracted on the security of the Petrograd assets, ${ }^{36}$ but somewhat more questionable is the court's expressed reluctance to admit that the acts of the Soviet government might be entitled to some effect. The court declared that the acts of the Russian government did not come within "the rule that acts or decrees, to be ranked as governmental, must proceed from some authority recognized as a government de facto."'37 In a famous dictum, Judge Cardozo stated:

[A] body or group which has vindicated by the course of events its pretensions to sovereign power, but which has forfeited by its conduct the privileges or immunities of sovereignty, may gain for its acts and decrees a validity quasi-governmental, if violence to fundamental principles of justice or to our own public policy might otherwise be done. ${ }^{38}$

This is hardly expressive of the view that unrecognized governments may have the "juridically cognizable" de facto existence to which Justice Breitel referred in Upright; one commentator has perceptively noted that Cardozo's statement

is nothing else but an inversion of the exception of public order. Instead of saying Soviet decrees are law but they will not be enforced if in a given case it is against public order, the court says: Soviet decrees are not law; but, exceptionally, when such non-recognition would lead to a result in opposition to public order, these decrees, nevertheless, will be enforced like law. ${ }^{39}$

As long as the Soviet government remained unrecognized, the New York courts did not apply to Soviet decrees any less "inverted" a public policy standard than that expressed by Cardozo in Sokoloff. ${ }^{40}$

government at all, if the power withholding recognition chooses thus to view it. In practice, however, since juridical conceptions are seldom, if ever, carried to the limit of their logic, the equivalence is not absolute, but is subject to selfimposed limitations of common sense and fairness ....

Id. at $165,145 \mathrm{~N} . \mathrm{E}$. at 918 .

36. Id. at 166-67, 145 N.E. at 919.

37. Id. at 166, 145 N.E. at 919.

38. Ibid.

39. Habicht, The Application of Soviet Laws and the Exception of Public Order, 21 AMr. J. INT'L L. 238, 252 (1927); see Borchard, supra note 26, at 269.

40. Speaking of the "inverted exception" expressed by Cardozo in Sokoloff, Professor Lauterpacht has noted that: "In the case in which that pronouncement was made, 
A year after Sokoloff was decided, the New York Court of Appeals decided Russian Reinsurance Co. v. Stoddard. ${ }^{41}$ Suit was brought in the name of a Russian corporation that had been dissolved by Soviet decree to compel the defendant bank to pay over money and securities that had been deposited pursuant to statute for the protection of American creditors and policyholders. The court of appeals affirmed a lower court decision dismissing the complaint on the ground that the corporation no longer existed.

Despite the vigorous dissent by Judge Crane that to deny the plaintiff's right to sue was to enforce the Russian decrees "by indirection," 42 the court indicated that it did not believe it was enforcing, or recognizing as law, any act of the Soviet government. The issue was not whether the court would give effect to the decrees of unrecognized Soviet Russia; decision of that question was specifically postponed. ${ }^{43}$ Rather, the court asked whether "within Russia, or elsewhere outside of the United States ... [the decrees] have actually attained such effect as to alter the rights and obligations of the parties in a manner we may not in justice disregard, regardless of whether or not they emanate from a lawfully established authority." 44

It was stated that although "for us tbe law of Russia, in its strict sense, may still be the law as it existed when the Czar ruled; for other nations the law of Russia is the law sanctioned by the Soviet Republic."45 The court recognized that it would be contrary to common sense to disregard the events that had changed the status of tbe corporation, dissolved by decree in its domicile eight years previously. ${ }^{46}$ This result was particularly necessary to avoid creating the danger of a double recovery against the defendant, one in the United States where the Soviet government and its claim to the funds

as well as in most of the other cases which approved of it, it was in fact followed by a refusal to treat as valid, with regard to the matter in hand, the legislation of the unrecognized government." LAUTERPACHT, op. cit. stipra note 26, at 147.

Other defendants have been as unsuccessful as the defendant in Sokoloff in attempting to avoid liability by pleading the effect of the Russian decrees. Accord, Dougherty v. Equitable Iife Assur. Soc'y, 228 App. Div. 624, 238 N.Y. Supp. 824 (1st Dep't), reversing 135 Misc. 103, 236 N.Y. Supp. 673 (Sup. Ct. 1929) (assignee of Russian national permitted to recover on contract to be performed in Russia); see Fred $S$. James \& Co. v. Second Russian Ins. Co., 239 N.Y. 248, 146 N.E. 369 (1925) ; cf. Hennenlotter v. Norwich Union Fire Ins. Soc'y, 207 N.Y. Supp. 588 (Sup. Ct. 1924) (joinder of Russian corporation whose existence was deemed unaffected by naturalization). See also Fred S. James \& Co. v. Russia Ins. Co. of America, 247 N.Y. 262, 160 N.E. 364 (1928), in which an assignment of the American assets of a nationalized corporation, executed by the former directors, was held to be valid and not a fraud on the corporate creditors. The court indicated very clearly that it might have reached a contrary result had the Soviet government been recognized.

The courts have occasionally found that persons who dealt with corporations after Russian decrees had purported to nationalize them were estopped. See Wulfsohn v. Russo-Asiatic Bank, II F.2d 715 (9th Cir. 1926); Joint Stock Co. of Volgakama Oil \& Chem. Factory v. National City Bank, 240 N.Y. 368, 148 N.E. 552 (1925).

41. 240 N.Y. 149, 147 N.E. 703 (1925).

42. Id. at $169,147 \mathrm{~N} . \mathrm{E}$. at 709 .

43. Id. at 156, 147 N.E. at 704.

44. Id. at 156, 147 N.E. at 704 . (Emphasis added.)

45. Id. at 162, 147 N.E. at 707 .

46. Id. at 162-63, 147 N.E. at 707 . 
in issue were not regarded as lawful, and another in a country that recognized the Soviet government.47 Accordingly, while the decrees were "not in full sense law,"48 their "actual effect" was recognized and the court held that the nonexistent corporation could not maintain suit. The defendant was allowed to retain custody of the funds until such time as the Soviet government received diplomatic recognition or the plaintiff's existence was re-established in Russia.49

The result reached in Stoddard was of course consonant with reality, and for that reason the decision was eminently correct. However, in arriving at its decision the court felt compelled to demonstrate elaborately that it was not treating the Soviet decrees as "law." The court's approach and its language give some indication of the nature of traditional law, for when a court intimates that the acts of a foreign government are not law but may nevertheless possess an "actual effect," the "juridical cognizability" that it attributes to the foreign government is minimal..$^{50}$ Certainly, the court of appeals' reluctance to admit the effects of the Soviet government's acts differs considerably from the appellate division's willingness to take frank note of the existence of the East German government. Moreover, the court of appcals soon retrcated from the realistic position it had taken in Stoddard. While the decision could be cited by the court in Upright to buttress its expression of traditional law, Stoddard merely said that Russian decrees, although not considered to be law in this country, can have some effect. Five years after Stoddard was decided, the court of appeals, in Petrogradsky Mejdunarodny Kommerchesky Bank v. National City Bank, ${ }^{51}$ implied that Russian decrees were not law in Russia. It held that Soviet decrees of dissolution had not ended the existence of the plaintiff corporation, which by a quorum of its directors under pre-Soviet bylaws ${ }^{52}$ had brought suit to recover deposits in New York. The opinion was not confined to the conclusion that the Russian decrees were not recognized as law in the United States; rather, it appeared to take the position that as "exhibitions of power" and not "pronouncements of authority" they were not law in Russia. ${ }^{53}$ Furthermore, the court applied

47. Id. at 167-68, 147 N.E. at 708-09.

48. Id. at $158,147 \mathrm{~N}$.E. at 705 .

49. Compare First Russian Ins. Co. v. Beha, 240 N.Y. 601, 148 N.E. 722 (1925), decided the same day as Stoddard, in which the court permitted suit by a corporation whose continued existence and the authority of whose directors was said to have been "conclusively established"; there was no danger of double liability, the court stated, because the defendant was sued as an officer of the state.

50. It should be recalled that Justice Breitel stated in Upright that traditional law attributes to de facto governments a "juridically cognizable" existence.

51. 253 N.Y. 23,170 N.E. 479 (1930).

52. See Severnoe Sec. Corp. v. London \& Lancashire Ins. Co., 255 N.Y. 120, 174 N.E. 299 (1931). Tihe court refused to allow the assignee of a nationalized Russian corporation to sue a British creditor in New York. The assignment had been executed by the surviving directors, who did not constitute a quorum under the pre-Soviet bylaws, and the Petrogradsky Bank case was distinguished on this ground.

53. The decrees of the Soviet Republic nationalizing the Russian banks are not law in the United States, nor recognized as law .... They are exhibitions 
the law of the Czars and of the Provisional government (although both authorities had ceased to exist more than a decade before the court wrote its opinion) in determining that the corporation still existed. ${ }^{54}$

Some of this confusion was dissipated by the court of appeals in $M$. Salimoff \& Co. v. Standard Oil Co. ${ }^{55}$ The Soviets had seized the plaintiffs' land and sold oil extracted from it to the defendant. Dismissing the complaint in an action for conversion, Judge Pound, writing for the court, stated that if the Soviet government were recognized as a de jure government, the validity of its acts would be determined by its own law and no other. ${ }^{68}$ The Department of State, in a memorandum quoted verbatim by the court, had indicated that while this country did not recognize the Soviet government, recognition was not withheld because the Soviet government did not exercise control and authority over the former Russian Empire; rather, the memorandum specifically stated, the Department was "cognizant of the fact that the Soviet regime is exercising control and power in territory of the former Russian Empire and the Department of State had no disposition to ignore that fact."

Incongruously professing independence despite its evident reliance on the memorandum, the court proceeded to state that "it follows that the question as to the validity of acts and decrees of a regime, not the subject of diplomatic recognition, becomes a matter to be decided by the courts in an appropriate case." 38 While it would not give full effect to the decrees of an unrecognized government, ${ }^{59}$ it could, however,

say that ... [the Soviet government] is a government, maintaining internal peace and order, providing for national defense and the gen-

of power. They are not pronouncements of authority. ... The personality created by law may continue unimpaired until law rather than might shall declare it at an end .... What is not to be lost sight of is that even so it is the law and not merely an assassin that must pronounce the words of doom.

Putting aside, then, as irrelevant the fiat of the Soviet Government that the jural consequence shall be death, we are brought to the question whether the law of the Imperial Government of Russia or of the later Provisional Government would have ascribed the consequence of death to the supervening changes irrespective of the fiat. ...

253 N.Y. at $28-30,170$ N.E. at $481-82$.

54. We find no statute or precedent that points with reasonable clarity to the conclusion that by the law of pre-Soviet Russia there has been an extinguishment of life as well as a suspension of activity. We find nothing in the Russian concept of juristic personality that leads to that conclusion, for there is nothing to show that the concept differs from our own. This being so, the presumption of continuance must tilt the balanced scales. The corporation survives in such a sense and to such a degree that it may still be dealt with as a persona in lands where the decrees of the Soviet Republic are not recognized as law. We think there is no substantial basis in the evidence for an opinion to the contrary.

Id. at $35-36,170 \mathrm{~N} . \mathrm{E}$. at 484.

55. 262 N.Y. 220,186 N.E. 679 (1933).

56. Id. at 224,186 N.E. at 681 .

57. Ibid.

58. Ibid.

59. Id. at 225, 186 N.E. at 681. 
eral welfare, carrying on relations with our own government and others. To refuse to recognize that Soviet Russia is a government regulating the internal affairs of the country, is to give to fictions an air of reality which they do not deserve. ${ }^{60}$

Accordingly, the "existing government" could not be ignored by the New York courts. It is clear, however, that in prior cases the court of appeals had itself maintained the fictions whose exaggeration it condemned. In Salimoff, it was released from them by the fortunate formulation of the State Department memorandum, which it assimilated to outright recognition. ${ }^{61}$

The results reached in other cases involving matters of private right are not very satisfactory. In Werenjchik v. Ulen Contracting Corp. ${ }^{62}$ the appellate division affirmed a workmen's compensation award and refused to reject certifications of the beneficiaries' births that had been authenticated by Soviet officials, on the ground that a government existed in Russia even if it was unrecoguized; the court of appeals, however, rested its affirmance on other proof of birth and indicated its desire to avoid the "troublesome" question of whether it could take "judicial notice" of an unrecognized government. ${ }^{63}$ Consistent, too, with the decisions involving the effects of nonrecoguition of the Soviet government is the decision of a New York trial court, which held that an administratrix appointed by a Mexican court could not sue because the government of Mexico was at that time unrecognized. ${ }^{64}$

Expressive of a distinctly different approach from that of these cases is Banque de France v. Equitable Trust Co. ${ }^{65}$ The plaintiff sued to recover gold that had allegedly been confiscated from it by the Soviets and that defendant averred it was holding for the State Bank of the Union of Soviet Socialist Republics. The United States District Court for the Southern District of New York denied the plaintiff's motion to strike defenses setting up the Soviet Union's title to the gold. Nonrecognition did not require the court to ignore the existence of the Soviet government or its ability to affect private rights. This was especially true as the plaintiff had alleged "that the Union of Soviet Socialist Republics is a foreign government . . . ."66 In a well known dictum, Judge Goddard stated that "a marriage which is valid under the laws

60. Id. at 227, 186 N.E. at 682 . The court expressly repudiated any language in prior cases "from which it might be inferred that the Soviet government is still to be regarded as a band of thieves." Ibid.

61. See LAUTERPACHT, op. cit. supra note 26, at 148 ("the wording of the certificate issued by the Secretary of State for the purposes of that case was such as almost to invite a clcar judicial pronouncement departing from previous practice"); Note, Effects in Private Litigation of Failure to Recognize New Foreign Governments, 19 U. CHI. L. REv. 73, 79 (1951).

62. 229 App. Div. 36, 240 N.Y. Supp. 619 (3d Dep't 1930).

63. 255 N.Y. 56, 173 N.E. 921 (1930).

64. Pelzer v. United Dredging Co., an unreported decision of the Supreme Court, New York County, discussed in Dickinson, The Unrecognized Government or State in English and Anerican Law, 22 MicH. L. REv. 29 (1923).

65. 33 F.2d 202 (S.D.N.Y. 1929), aff'd, 60 F.2d 703 (2d Cir. 1932).

66. Id. at 207 . 
of the present government of Russia is quite universally regarded as valid in this country."67 Applying the "inverted" public policy test expressed by Judge Cardozo in Sokoloff, the court found that "fundamental justice" would be violated and the defendant would be threatened with double liability if it were precluded, solely because of nonrecognition, from interposing the defense of Soviet title to the gold..$^{88}$

\section{B. The "Baltic Ship" Cases}

Relevant, too, in ascertaining traditional law are the so-called "Baltic ship" cases of more recent vintage, in which several federal courts expressed not only an unwillingness to give effect to the decrees and existence of unrecognized governments, but also seemed to take the position that in matters involving nonrecognition the courts must follow the State Department's view as to the disputes they may decide and the laws they may apply.

After the annexation of Latvia, Estonia, and Lithuania by the Union of Soviet Socialist Republics in 1940, the Soviet governments of those countries, which were (and still are) unrecognized, issued decrees purporting to confiscate all privately owned shipping. In The Maret, ${ }^{00}$ an American representative of an Estonian state agency, to which a decree had purported to transfer a vessel, attempted to enforce a statutory lien for advances that it had made "upon the orders of the owner." The Acting Consul General in New York of the pre-1940 Estonian government intervened as the former owners' attorney in fact. The Third Circuit refused to allow a statutory lien becatse it would not recognize that the nationalization decrees had made the Estonian agency the "owner" of the ship. The Secretary of State had certified that the United States did not recognize the absorption of Estonia by the Union of Soviet Socialist Republics or the "legality of the so-called 'nationalization' laws and decrees...."71 This certification was deemed binding, because

67. Id. at 205 .

68. Id. at 206. Another exception to the usual judicial reluctance to acknowledge the existence of unrecognized governments is Government of Mexico v. Fernandcz (1923), an unreported decision of the Supreme Court of Essex County, Massachusetts, discussed in Wright, Suits Brought by Foreign States with Unrecognized Goverminents, 17 AMr. J. INT'L L. 742, 743-44 (1923). An attorney appearing for the then unrecognized Obregon regime in Mexico obtained an order restraining a former Mexican treasury employee from removing 140,000 Mexican pesos from a Massachusetts bank in which he had placed them. In a communication presented to the court, the Undersecretary of State stated that although the plaintiff regime was unrecognized, American recognition of the "Mexican state itself" as an "international person" was unaffected. The court noted that the regime then in power in Mexico effectively controlled the country, maintained representatives in the United States who discharged the functions of consuls and chargés d'affaires and, moreover, that negotiations that could result in recognition were pending before representatives of the regime and American representatives. The Obregon regime was indeed recognized several months after the case was decided.

69. 145 F.2d 431 (3d Cir. 1944).

70. 41 Stat. 1005 (1920), 46 U.S.C. \$ 971 (1958).

71. 145 F.2d at 438. 
"acts of the Executive in the 'political' field are binding upon our courts,"72 and because nonrecognition is an executive act that necessarily instructs the courts as to which decrees they can "recognize." Interpreting the New York Court of Appeals' decision in Stoddard as intimating that executive nonrecognition leaves the courts free to determine the effect of acts of the unrecognized government, the Third Circuit disagreed. The State Department's clear expression of executive policy could not be disregarded $:^{73}$

When the fact of nonrecognition of a foreign sovereign and nonrecognition of its decrees by our Executive is demonstrated as in the case at bar, the courts of this country may not examine the effects of decrees of the unrecognized foreign sovereign and determine rights in property, subject to the jurisdiction of the examining court, upon the basis of those decrees. ${ }^{74}$

Judge Goodrich concurred on the ground that the court should give no effect to confiscatory decrees that had purported to affect property "many hundreds of miles" outside the territorial jurisdiction of the confiscating country. ${ }^{75}$

Similar views were expressed in Latvian State Cargo \& Passenger S.S. Line v. Clark. ${ }^{76}$ In that case, a Russian corporation in which title to three Latvian ships had been vested by a nationalization decree brought an action under the Trading With the Enemy Act ${ }^{77}$ to recover the insurance proceeds on the vessels, but the court granted summary judgment for the defendant. The decision could have rested on the fact, noted by the court at the outset, that the ships had not been in Latvian waters when the nationalization decrees were issued. However, the court went further, asserting that "a court may not give effect to an act of an unrecognized government, for by so doing it would tacitly recognize the government, invade the domain of the political department, and weaken its position."78 The decision was affirmed by the Court of Appeals for the District of Columbia. ${ }^{70}$ No mere failure to recognize the Soviet-dominated Latvian government was involved, the court stated, but a strong executive policy against condoning in any way the Soviet occupation of Latvia. Although in the absence of such a policy the usual conflict of laws rules might apply, in the case before it the court declared that it was bound by the State Department's certification that neither the incorpo-

72. Id. at 440 .

73. The court stated that the decision was compelled by United States v. Pink, 315 U.S. 203 (1942), which held that the New York assets of a nationalized Russian insurance company became the property of the United States through the combined effect of the extraterritorial reach of the nationahization decree and the so-called Litvinov assignment of 1933, by which the Soviet Union transferred to the United States all amounts that might be due to it.

74. 145 F.2d at 442 .

75. Id. at 44445 .

76. 80 F. Supp. 683 (D.D.C. 1948).

77. 40 Stat. 419 (1917), as amended, 50 U.S.C. ApP. \& 9(a) (1958).

78. $80 \mathrm{~F}$. Supp. at 684 .

79. Sub nom. Latvian State Cargo \& Passenger S.S. Line v. McGrath, 188 F.2d 1000 (D.C. Cir.), cert. denied, 342 U.S. 816 (1951). 
ration of Latvia into the Union of Soviet Socialist Republics nor the legality of the "so-called" nationalization decrees was recognized by this country. ${ }^{80}$ Salinnoff was distinguished as a case in which the State Department had "refused to certify a policy of hostility to ... the unrecognized [Soviet government]."81

The "Baltic ship" cases appear to rest most firmly on the traditional public policy objections to granting extraterritorial effect to confiscatory decrees. And, as one opinion observed, American policy hostile to the Baltic countries was clearly indicated by the freezing of their citizens' American assets to prevent transfer to rulers considered unlawful. 82 The "Baltic ship" cases, then, provide no support for the proposition that the State Department is the ultimate authority concerning either the law that should be applied in disputes arising from commercial transactions with unrecognized governments and entities created by them, or the plaintiffs who should be permitted to enforce such transactions in American courts. Yet the dicta in these cases are the strongest expressions of the view that the courts, in deciding matters complicated by nonrecognition, must depend on the State Department to provide authoritative gnidance to the courts on the laws and the governments that may be judicially "recognized." 83

\section{Traditional Law Appraised}

The foregoing summary should indicate that the "traditional law" to which Justice Breitel referred is neither as traditional nor as unambiguous as his positive language might indicate. The cases are muddled and contain conflicting views and expressions.

So far as the New York cases are concerned, it is clear that until Salimoff, in which the court received tacit permission from the State Department to adjudicate the dispute, the courts had labored uncertainly in their efforts to determine the extent, if any, to which the laws and decrees of the unrecognized Soviet government should be given effect. It is evident, too, that the judicial reluctance to give effect to Russian decrees and laws stemmed in part -and more than formally-from the fact that the Soviet government was unrecognized. ${ }^{84}$

80. Id. at 1002-04.

81. Id. at 1002. See text accompanying notes $57-60$ supra.

82. 145 F.2d at $431 \& 442$ n. 43 .

83. See also A/S Merilaid \& Co. v. Chase Nat'1 Bank, 189 Misc. 285, 287, 71 N.Y.S.2d 377, 379 (Sup. Ct. 1947), in which the court, holding that the defendant bank was required to pay over deposits to the former directors of a corporation nationalized by an Estonian decree, stated: "The legality of the nationalization laws and decrees or of any of the acts of the regime now functioning in Estonia is not recognized by the government of the United States."

84. But see Vladikavkazsky Ry. v. New York Trust Co., 263 N.Y. 369, 379, 189 N.E. 456,460 (1934): "The fact that the present Russian government was not recognized was not the basis of our refusal to give effect to its decrees nationalizing corporations and confiscating their property." 
Moreover, examination of the cases reveals that they frequently. express unwillingness to give effect to the acts of the unrecognized government or to admit that it was a government, while contemporaneously admitting;, reluctantly and in a highly convoluted fashion, that the existence of the Soviet government could not be ignored. Sometimes, as in Stoddard, Wulfsohn, and Salinoff, the New York Court of Appeals expressed an awareness of the post-revolutionary problems of doctrine and policy in realistic language indicating the court's sensitivity to actual events; but often, as in Stoddard and Petrogradsky Bank, the court attempted resolution of these problems in both conceptualistic and moralistic terms. Because these cases were usually concerned with the violent consequences of revolution or war, they did not generate consistent expressions of judicial willingness to recognize the effects of acts of unrecognized governments, even on private rights. Unfortunately, much of the language in the cases also strongly suggests that the acts of unrecognized governments are something less than law because the governments are unrecoguized, ${ }^{85}$ and are to be ignored as much as possible because of both conceptualistic reasons and supposed considerations of policy, which may or may not be expressed by the State Department. Consequently, the courts have created the danger that their language will be uncritically extended to cases involving private rights and transactions, to which that language was not intended to apply. There is a related danger that judicial dependence on the State Department, such as that in the Salinoff and "Baltic ship" cases, will be uncritically transferred to the cases involving private rights and transactions.

\section{The De Facto Principle}

\section{A. Definition}

There is, however, an alternative approach to the problem of the effect of nonrecoguition on matters of private right. Dicta in several of the cases discussed above and in a number of other decisions that did not involve nonrecognition but are analogous suggest use of the "de facto principle." Simply

85. Compare Lauterpacer, Recognition in InTERnational LaW 151 (1948): "In the countries of the European continent the courts, with slight exceptions, have adopted the view that prior to recognition the unrecognized authority and the acts emanating from it are a mere nullity." A notable exception to this view is "Exportchleb" Ltd. v. Goudeket, [1935-1937] Ann. Dig. 117 (No. 36) (Neth.), in which the District Court of Amsterdam held that an assignee of a Soviet trade delegation could sue in the Netherlands although the Soviet government was unrecognized. The court also stated:

the defence [that neither the Soviet government nor its assignee could sue in a Dutch court] must be rejected on the ground that though non-recognition of the actual Russian Government by the Netherlands involved, indeed, the absence of diplomatic intercourse between the two States, that non-recognition by no means entailed the consequence that the de facto Government of the Russian State was incompetent to appear for Russia in matters of civil law in the Id. at 118 .

Courts of Holland. 
stated, the courts will give effect to the consequences of the existence of a political authority the legitimacy of which is controverted or denied. $D e$ factoism does not require the courts to disregard policy considerations; rather, it requires them to eschew total submission to the imagined demands of policy for thoughtful appreciation of the manner in which policies, realistically weighed, should influence results.

The most notable expression of de factoism is the United States Supreme Court's post-Civil War formulation of the test by which the effect and validity of the enactments of the Confederate states would be determined:

It may be said, perhaps with sufficient accuracy, that acts necessary to peace and good order among citizens, such for example, as acts sanctioning and protecting marriage and the domestic relations, governing the course of descents, regulating the conveyance and transfer of property, real and personal, and providing remedies for injuries to person and estate, and other similar acts, which would be valid if emanating from a lawful government, must be regarded in general as valid when proceeding from an actual, though unlawful, government; and that acts in furtherance or support of rebellion against the United States, or intended to defeat the just rights of citizens, and other acts of like nature, must, in general, be regarded as invalid and void.86

A group of post-Civil War decisions remain the best known examples of application of the de facto principle. It suffices only to recall that the Supreme Court, applying the test quoted above, upheld acts of the Confederate states that were deemed not to have been in direct furtherance of the rebellion. Thus, a rebellious state could create corporations with capacity to sue after the war $;^{87}$ a contract was not invalid solely because it was payable in Confederate money; ${ }^{88}$ a Confederate state bank could issue bills that were legal tender for the payment of taxes. ${ }^{89}$ In converse application of the de facto test, the Court held that title to bonds used to finance the military needs of the rebellion could not be transferred $;^{00}$ a debt was not discharged by payment of the sum owed to a Confederate state treasury pursuant to a statute requiring such disposition of debts owed to "alien enemies"; ;1 a purchaser of cotton from the Confederacy could not regain the proceeds when the cotton had been captured and sold under the Captured and Abandoned Property Act $; 2$ no action could be brought on a promissory note given in consideration of a sale of goods to a purchasing agent for the Confederacy; $; 3$ no title was

86. Texas v. White, 74 U.S. (7 Wall.) 700,733 (1868).

87. United States v. Insurance Cos., 89 U.S. (22 Wall.) 99 (1875). See the discussion of this case in text accompanying notes 132-34 infra.

88. Thorington v. Smith, 75 U.S. (8 Wall.) 1 (1868).

89. Keith v. Clark, 97 U.S. 454 (1878).

90. Texas v. White, 74 U.S. (7 Wall.) 700 (1868).

91. Williams v. Bruffy, 96 U.S. 176 (1877).

92. Sprott v. United States, 87 U.S. (20 Wall.) 459 (1874).

93. Hanauer v. Doane, 79 U.S. (12 Wall.) 342 (1870). 
conferred on a purchaser of stock in a South Carolina corporation that had been sequestrated and its stock sold under a Confederate statute requiring such action to be taken with property owned by "alien enemies." dicial test, the test employed in the post-Civil War cases was a rough ${ }^{95}$ but workable one.

In other notable instances not arising from the Civil War, the courts, to preserve executed transactions, applied to them rules of law that, although emanating from sovereigns whose authority was debatable, were appropriate because of factual circumstances. Thus, United States $v$. Rice, ${ }^{98}$ cited by Justice Breitel in Upright, held that Americans who had paid customs duties to the British during the British occupation of the port of Castine, Maine, during the War of 1812 were not liable for repayment of those duties to American authorities after the war. Another well known decision is Keene v. McDonough, ${ }^{97}$ in which the Supreme Court upheld a title derived from a decree issued by Spanish authorities in Louisiana after that territory had been ceded but before the United States acquired possession of it.

These decisions provide, of course, only limited support for judicial extension of the de facto principle to the nonrecognition area. ${ }^{98}$ The problems in all of these cases arose as the aftereffects of conflicts or other situations whose outcomes were settled by the time the controversies reached the courts. In none of them was it suggested that an existing international situation compelled results different from those actually reached by the courts, or compelled judicial deference to the State Department's political perspectives on the problems posed. In the Civil War cases, the Court was sensitive to the problem of reintegrating into the Union the states that had attempted to secede.98 Upsetting private transactions that had

94. Dewing v. Perdicaries, 96 U.S. 193 (1877).

95. The Court occasionally encountered difficulty in distinguishing acts directly in furtherance of the rebellion from acts that were not. Compare Horn v. Lockhart, 84 U.S. (17 Wall.) 570 (1873) (trustee denied credit for investment in Confederate bonds), with Baldy v. Hunter, 171 U.S. 388 (1898) (guardian not liable for investment in Confederate bonds).

96. 17 U.S. (4 Wheat.) 246 (1819).

97. 33 U.S. (8 Pet.) 308 (1834).

98. The Civil War cases in particular have received close attention from writers who have urged their persuasiveness as an analogy for the nonrecognition area. E.g., JAFFe, Judicial Aspects of Foreign Relations 168-75 (1933); Fraenkel, The Juristic Status of Foreign States, Their Property and Their Acts, 25 CouUM. L. REv. 544 (1925). Cf. Connick, The Effect of Soviet Decrees in American Courts, 34 Yale L.J. 499, 508 (1925), who considered Judge Cardozo's dictum in Sokoloff consistent with the post-Civil War cases. Contra, JAFFe, op. cit. supra at 174 n.179; Untermyer, Judicial Interpretation of the Soviet Decrees in Relation to Private Rights, 1 GEo. WASH. I. REV. 471, 474 (1933).

99. See, e.g., Ford v. Surget, 97 U.S. (7 Otto) 594 (1878), in which the Court held that a Confederate officer was not liable in tort for ordering that the plaintiff's cotton be burned to prevent it from falling into the possession of advancing Union forces. The action had been ordered pursuant to a Confederate statute declaring that military commanders had the duty to destroy cotton to prevent its capture. Mr. Justice Clifford, concurring, stated that a judicial refusal to consider the Confederate states as having constituted a de facto government would cause Confederate soldiers to be 
not been entered into with any intent to injure the Union would hardly have aided this task. It is also true that the courts at times ignored the existence of the Confederacy, and upheld some of its enactments "as they were found reflected in the legal structure of the various states," 100 thus maintaining the principle that the states had never left the Union. Nevertheless, the cases are valid and instructive and Professor Jaffe's observations are apposite: "the[se] cases have a value for us in their reliance on de factoism as a broad principle needful for the conservation of the social order."101

\section{B. The De Facto Principle in Upright}

The indecisive responses to nonrecognition in the cases decided by the New York Court of Appeals after the Russian Revolution, the extreme language in some of those cases and in the "Baltic ship" cases, and the older cases embodying the de facto principle were thus available to Justice Breitel when he wrote the opinion of the court in Upright. His choice is apparent; by extracting the minor theme of the New York cases and setting aside stronger contrary language and results that were at best ambiguous, by drawing on the post-Civil $\mathrm{War}$ cases, and by adding his own siguificant comments, he produced an important statement of the de facto principle in an area in which it has long required affirmation.

Thus, immediately after his statement concerning traditional law Justice Breitel plucked from Russian Reinsurance Co. v. Stoddard ${ }^{102}$ an exposition of the respective roles of executive and judiciary, and the effect of the executive's decision to withhold recognition from a government:

[The] rule [of an unrecognized government] may be without lawful foundation; but lawful or unlawful, its existence is a fact and that fact cannot be destroyed by judicial concepts. The State Department determines whether it will recognize its existence as lawful, and until the State Department has recognized the new establishment, the court may not pass upon its legitimacy or ascribe to its decrees all the effect which inheres in the laws or orders of a sovereign. The State Department determines only that question. It cannot determine how far the private rights and obligations of individuals are affected by acts of a body not sovereign, or with which our government will have no dealings. That question does not concern our foreign relations. It is not a political question, but a judicial question. ${ }^{103}$

Justice Breitel then added his own formulation:

subjected to criminal penalties for their acts in combat. "Once enter that domain of strife, and countless litigations of endless duration may arise to revive old animosities and to renew and inflame domestic discord, without any public necessity or individual advantage." $I d$. at 623 .

100. JAFFE, op. cit. silpra note 98 , at 173.

101. $I d$. at 175 .

102. 240 N.Y. 149, 147 N.E. 703 (1925). at 420 .

103. Id. at 158, 147 N.E. at 705 , quoted at 13 App. Div. $2 d$ at 38,213 N.Y.S.2d 
[O]nly limited effect is given to the fact that the political arm has not recognized a foreign government. Realistically, the courts apprehend that political nonrecognition may serve only narrow purposes. While the judicial arm obligates itself to follow the suggestions of the political arm in effecting such narrower purposes, nevertheless, it will not exaggerate or compound the consequences required by such narrow purposes in construing rights and obligations affected by the acts of unrecognized governments . . ..$^{104}$

Thus nonrecognition did not mean, and the court would not infer from it, the necessity to disregard the inevitable effect of acts and laws of an unrecognized government on private rights and transactions.

The court cited Salimoff, in which the New York Court of Appeals had held that a purchaser from the Soviets of property confiscated in Russia could take good title, and Banque de France, in which the defendant was permitted to raise the defense that title to allegedly confiscated gold was in the Soviet State Bank. In Upright, unlike Salimoff and Banque de France, no confiscatory acts were involved. ${ }^{105}$ In this less extreme situation, "the internal acts of the East German Government, insofar as they concern the parties here, should be given effect generally."106 The issues of the "jural status" of the East German corporation, which was the plaintiff's assignor, and its capacity to transfer title or sue were not presented by the pleadings before the court. ${ }^{107}$ When they are presented, they are issues to be determined "by reference to the actual facts-the realities of life-occurring in the territory controlled by a de facto government, unless, of course, the contemplated juridical consequences of such 'facts' can be properly related as inimical to the aims and purposes of our public or national policy . ..."108 To this, Justice Breitel added:

It is a false notion, if it prevail anywhere, that an unrecognized government is always an evil thing and all that occurs within its governmental purview are always evil works. There are many things which may occur within the purview of an unrecognized government which are not evil and which will be given customary legal significance in the courts of nations which do not recognize the prevailing de facto government. In a time in which governments with established control over territories may be denied recognition for many reasons, it does not mean that the denizens of such territories or the corporate creatures of such powers do not have the juridical

104. 13 App. Div. 2d at 39, 213 N.Y. Supp. 2d at 420.

105. Id. at 40,213 N.Y.S.2d at $421-22$. In this connection, Justice Breitel distinguished Luther v. Sagor \& Co., 1 K.B. 456, rev'd on other grounds, [1921] 3 K.B. 532 (C.A.). Luther had reached a result contrary to that of Salimoff, on similar facts. A purchaser from the Soviets of property seized from the plaintiff was held liable for conversion, but the decision was reversed after the British Government recognized the Soviet government while the appeal was pending. Justice Streit had relied heavily on Luther, but with some understatement Justice Breitel pointed out that Luther had not been viewed as "authoritative" in Salimoff.

106. 13 App. Div. 2d at 40,213 N.Y.S.2d at 421.

107. Id. at 40,213 N.Y.S.2d at 422 .

108. Id. at 40, 213 N.Y.S.2d at 422. 
capacity to trade, transfer title, or collect the price for the merchandise they sell to outsiders, even in the courts of nonrecognizing nations .... 109

Moreover, Justice Breitel's opinion demonstrates the manner in which considerations of national policy must affect the de facto principle. After observing that nonrecognition did not affect the capacity of citizens or entities subject to the authority of the unrecognized government to trade, Justice Breitel measured the enforceability of the transaction in Upright, a product of that trade, by weighing the relevant policies:

[I]n order to exculpate defendant from payment for the merchandise it has received, it would have to allege and prove that the sale upon which the trade acceptance was based, or that the negotiation of the trade acceptance itself, was in violation of public or national policy. Such a defense would constitute one in the nature of illegality and if established would, or at least might, render all that ensued from the infected transaction void and unenforceable. Defendant buyer cannot escape liability merely by alleging and proving that it dealt with a corporation created by and functioning as the arm of and instrumentality of an unrecognized government. . . . In order for such transaction or the assignment to violate national or public policy, it must be shown either to violate our laws or some definite policy. If the national government does not administratively forbid, or if it facilitates, the purchase and delivery into this country of East German typewriters, and no law forbids it, then defendant buyer will be hard put to show the 'illegality' of the underlying transaction, or the assignment, and thereby avoid payment of the price for such merchandise. . . . The effect of nonrecognition, used by defendant as some sort of umbrella to protect it from liability, is not the answer. ${ }^{110}$

Appraisal of the consequences of nonrecognition led to the conclusion that the East German government, its laws, and the existence of entities created by it could be given effect by the court without violating any policy; the ensuing appraisal of the policies applicable to the transactions out of which the case itself had arisen resulted in the decision that suit should not be barred. The precise approach employed in thus meeting the issues presented in Upright is clearly a considered, policy-oriented de factoism.

Cardozo had himself once hinted at the balanced approach of $U$ pright in a dictum to the effect that the post-Civil War cases furnished an analogy valid for use in nonrecognition cases ;11 in the Petrogradsky Bank case he

109. Id. at 41,213 N.Y.S.2d at 422 .

110. Id. at 41-42, 213 N.Y.S.2d at 422-23. These remarks should be compared with Justice Streit's concern that the plaintiff not have greater rights than his assignor. Justice Breitel's focus on the legality of the transactions between the parties, rather than on the issue of whether the assignor could have maintained suit, is consistent with the liberal construction that the New York courts have given to the New York real-partyin-interest statute, N.Y. CIV. PRAC. Acr \& 210. See, e.g., McBride v. The Farmer's Bank, 26 N.Y. 450 (1863) ; Wagner v. Braunsberg, 5 App. Div. 2d 564, 173 N.Y.S.2d 525 (1st Dep't 1958).

111. Sokoloff v. National City Bank, 239 N.Y. 158, 165, 145 N.E. 918-19 (1924). 
stated that "the every-day transactions of business or domestic life are not subject to impeachment, though the form may have been regulated by the command of the usurping government ....'112 On still another occasion, Cardozo intimated that the de facto principle could appropriately be applied in cases involving private rights and transactions. ${ }^{113}$ However, he never had occasion to venture beyond the "inversion" of the normal public policy exception. ${ }^{114}$

It should be clear, however, that Justice Breitel's opinion in 'Upright did not invert normal judicial values. No policy generated by the mere fact of nonrecognition required the court to refrain from deciding the case before it; nor did nonrecognition bar the court from taking cognizance of the unrecognized government or its laws to the extent required to permit suit by a plaintiff who was the successor in interest of an alleged instrumentality of the government. Further, the court in dicta implied that it would take the same view of the transactions and the possibly relevant policies if the problem presented were that of the direct application to the case of a rule of East German law. Suit was permitted, and East German law would presumably be applied, not because reasons of. policy required such results, but because no reason of policy affirmatively prohibited them.

\section{THe Ünrecogñzed Government As Plaintiff}

Upright indicates that whenever trade with an unrecognized government ,or entities and individuals subject to its authority is permitted, the problem of whether they can enforce in American courts transactions entered into as part of that trade may arise. Use of the de facto principle suggests itself as a means of solution. Here, however, the principle conflicts with the rule, regarded by the courts as established, that forbids suit by, unrecognized goveruments.

Judge Cardozo stated that in the post-Civil War cases acts of the Confederate states were heid to be void "when they worked injustice to citizens of the Union, or were in conflict with its public policy," and were upheld when they were "just in operation and consistent with public policy." Such an analogy, he continued, "suggest[s] the thought that, subject to like restrictions, effect may at times be due to the ordinances of foreign governments which, though formally unrecognized, have notoriously an existence as governments de facto." Immediately after these words, however, he uttered the dictum discussed above in which he "inverted", the test of the post-Civil War cases.

112. Petrogradsky Mejdunarodny Kommerchesky Bank v. National City Bank, 253 N.Y. 23, 28-29, 170 N.E. 479, 481 (1930).

113. We do not say that a government unrecognized by ours will always be viewed as non-existent though the sole question at issue has to do with a transaction between the unrecognized Government and a citizen or subject of a government by which recognition has been given. To say this might seem to imply, for illustration, that a voluntary conveyance by a British citizen to the Soviet government, would be viewed as a nullity in the United States on some theory that the grantee though recognized in Great Britain was without capacity to take.

Fred S. James \& Co. v. Second Russian Ins. Co., 239 N.Y. 248, 256, 146 N.E. 369, 370-71 (1925).

114. See text accompanying notes $38-40$ supra. 


\section{A. The Cibrario Rule}

Although Justice Breitel made clear and effective use of the de facto principle to permit suit by an American assignee of an East German corporation, he did not consider the question of whether tbat principle would permit suit by the East German government itself. Both he and Justice Steuer, concurring, assumed that governments diplomatically unrecognized by this country can not sue in American courts. Justice Breitel cited, as did Justice Streit in the court below, Russian Socialist Federated Soviet Republic v. Cibrario, 110 as authority for that proposition. In that case, the Soviet government was barred from bringing suit for misappropriation of its funds in the United States. The unrecognized Soviet government had delivered $\$ 1,000,000$ to the American Commercial Attaché in Moscow for deposit in a New York bank, subject to the draft of Cibrario, a purchasing agent who was obligated by contract with the Russians to purchase certain equipment for them in the United States. 116 Alleging that he had committed substantial frauds, the Russian government attempted to sue for an accounting. The New York Court of Appeals held that the plaintiff could not sue because nonrecognition barred the extension to it of international comity, defined as "reciprocal courtesy."117 The court reasoned that comity, based on friendship, was accorded to other nations by the exclusively executive act of recognition. Furthermore, jurisdiction depended on the law of the forum, which in turn depended on public policy as expressed by the State Department. ${ }^{118}$

The Cibrario decision has inspired vigorous and watranted criticisn.. ${ }^{110}$

115. 235 N.Y. 255,139 N.E. 259 (1923).

116. See Russian Socialist Federated Republic v. Cibrario, 198 App. Div. 869, 870, 191 N.Y. Supp. 543, 544 (1st Dep't 1921), reversing an order for the appointment of a receiver pendente lite and granting an injunction.

117. 235 N.Y. at 258,139 N.E. at 260.

118. See the excerpt from the court of appeals opinion quoted in text accompanying note 12 supra.

119. Fraenkel, supra note 98 , at 551 : "[T]his result is open to objection upon equitable grounds, as permitting breaches of trust. In cases such as this, in which no political -considerations of any kind are involved, it could well have been decided that the right to sue did not depend upon recognition."

Dickinson, The Unrecognized Govermment or State in English and Ancrican Law, 22 Mich. L. REv. 118, 123 (1923): "Must it be said, then, that the funds of an unrecognized government are free plunder for anyone who has a mind to help himself?" Professor Borchard, referring to the fact that the misappropriated money had originally been transmitted through the American Commercial Attaché in Moscow, noted, "If the stability and existence of that government was acknowledged to the point of an American public official accepting its money for investment in the United States, it seems a strange anomaly that it was unable to receive judicial protection when it was despoiled of its investment in American territory." Borchard, The Unrecognized Government in American Courts, 26 AMER. J. INT'L L. 261, 266 (1932); see JAFFE, op. cit. sipra note 98, at $149-56$.

However, the Cibrario decision has found a few defenders: "In support of the rule it must be said that such a denial of the right to sue, gives the State Department additional power in its negotiations with the unrecognized nation." HERVEY, THE LEGAL EFFECTS of RECOGNITION IN INTERNATIONAL LAW 118 (1928); cf. Tennant, Recognition Cases in American Courts, 1923-1930, 29 MICH. L. REv. 708, 713 (1931): "[the right to sue] does not follow from sovereignty alone, but is dependent, if not on comity, at 
Since the transfer of Russian funds to this country was made to further ordinary commercial activities, which were legal and had been facilitated by a representative of the United States Government, it was hardly equitable to deny the Russian government a remedy for a wrong committed against it in the United States. ${ }^{120}$ In addition, the court's conclusion that policy prevented the Soviet government from instituting suit on the particular transaction involved does not follow, necessarily, from the fact of nonrecognition. As Professor Jaffe has' said in commenting on Cibrario:

It is one thing to deny a state favors because we do not like its government; it is quite another to hold up its own funds. ... There is nothing in the statutes, nothing in the nature of recognition as a process, which compels the result. It proceeds from an idea that where a case has a bearing on foreign affairs, the court must subordinate its ordinary procedures and adjust its decision to the supposed needs of the foreign office. It seems to us that the relation between the two departments should be one of mutual respect. To allow suit contradicts nothing that the Department of State has said or done, creates no conflict between the departments. If it places limits on the effectiveness of a particular foreign policy, that merely testifies that the claims of foreign policy are no more absolute than any other. ${ }^{121}$

In deciding Cibrario, the court of appeals failed to evaluate properly the "claims" of foreign policy. No rival authority purporting to be the rightful government of Russia was party to the suit. To reach its decision on the substantive issues in the case, the court would not have been required to pass on the legitimacy of the Soviet government. Nor: would recovery by the plaintiff have infringed on any policy except that against aiding the Soviet government to obtain funds, a policy that was erroneously imagined by the court to exist despite contrary indications from the facts before it. An occasion to. deny access to our courts to a plaintiff who would transmit his recovery to a nation to which executively-formulated policy affirmatively. denies American funds might well arise, ${ }^{122}$ but Cibrario was not such a case. Cibrario indicates, as does Upright, that foreign policy considerations need not always require the courts to bar suit or recovery by an unrecognized government.

\section{B. The Appellate Division's Formulation of the Cibrario Rule}

The appellate division in Upright, however, adhered to the Cibrario rule. Justice Breitel, citing Cibrario, stated that "if the unrecognized government were allowed to sue, this would be deemed recognition of jural

least on friendly diplomatic relations, and certainly would be refused also in the case of a government with whom diplomatic relations had been severed as a result of war."

120. See Borchard, sipra note 119, at 265-66.

121. JAFFE, op. cit. supra note 98 , at $155-56$.

122. See Bank of China v. Wells Fargo Bank \& Union Trust Co., 104 F. Supp. 59 (N.D. Cal. 1952), modified, 209 F.2d 467 (9th Cir. 1953). 
status ...."123 This is an overstatement of Cibrario itself. The basis for the court of appeals' decision in Cibrario was not the nonexistence of the unrecognized government, but the necessity, supposedly dictated by national policy, of excluding the Soviets from our courts. Justice Breitel's formulation creates other problems. The breadth of his statement bespeaks an intent to apply the Cibrario rule to suits arising from commercial transactions that, like the one in Upright, are not themselves illegal. Such a view violates both reason and necessity in the same manner and on the same grounds that they were violated in Cibrario. Furthermore, Justice Breitel's opinion gives no indication that he considered the possibility of a contradiction in using both the de facto principle and the Cibrario rule. Perhaps there was no necessity to consider such a conflict, since only traditional law was purportedly being applied. Moreover, the issue of whether an unrecognized government could sue was not before the court. However, Justice Breitel considered the rule and its reach, and it is therefore appropriate to consider the inconsistency between his formulation of the rule and the approach that he took to the problem of nonrecognition generally.

Justice Breitel's mention of "jural status" is both unnecessary and confusing. The term smacks of the theory that a government does not exist until it is recognized, an implication plainly contrary to the realism of Justice Breitel's expressed views on the excessiveness of inferring from political nonrecognition the necessity of completely ignoring the existence of the unrecognized government. Use of the term also tends to render deceptively abstract a highly practieal problem the resolution of which is not entirely aided, since talk of "jural status" may obscure awareness of the fact that if commercial transactions are permitted between Americans and persons or entities subject to the authority of unrecognized governments, it is anomalous to deny a forum in which disputes arising from such transactions may be resolved.

Additionally, it might be recalled that the court of appeals, in Wulfsohn v. Russian Socialist Federated Soviet Republic, ${ }^{124}$ held that the unrecognized Soviet government was entitled to sovereign immunity. The court in that case asserted that the defendant was the de facto government of the country it claimed to rule, and because it was a sovereign that had not consented to be sued, no suit could be brought against it. Surely this decision accorded the Soviet government "jural status." There may be a considerable difference between allowing an unrecognized government to assert its existence offensively by bringing suit and permitting it to make the plea of sovereign immunity defensively, but "jural status" is not helpful in explaining that

123. 13 App. Div. $2 d$ at 39, 213 N.Y.S.2d at 421 (footnote of the court). (Emphasis added.)

124. 234 N.Y. 372, 138 N.E. 24 (1923), appeal dismissed, 266 U.S. 580 (1924). 
difference. The cases denying unrecognized governments access to domestic courts are reconcilable with the cases granting sovereign immunity to unrecognized governments, in that the results in both types of cases have the effect of keeping the governments out of American courts. The results are also reconcilable on a policy basis; possible conflict with the State Department in either type of case is thus averted. However, no concept of "jural status" is necessary to the results reached.

The preceding discussion of Cibrario indicates that it may not always be necessary to infer from nonrecognition a rule that absolutely excludes unrecognized governments from American courts. If the inference is drawn, however, the reasons underlying it should be explicitly stated and not clouded by adverting to "jural status."

\section{The Suggested Corporate Exception}

The conflict between de factoism and unreasoned unwillingness to give effect to the existence of a functioning unrecognized government has been demonstrated to exist in earlier decisions and in Upright as well. Justice Breitel's formulation of the Cibrario rule is, of course, more consistent with the approach that attempts to restrict as much as possible any judicial acknowledgment of the existence of an unrecognized government. The conflict between the two tendencies is, however, even more strikingly illustrated by the dictum that Justice Breitel added to his statement of the Cibrario rule. Citing United States v. Insurance Cos.,"125 he stated: "Note that the corporation perhaps could sue ...."128 The suggestion that a corporation created by an unrecognized government might be able to bring suit was reinforced later in the opinion: "The question whether ... [the East German government's corporate instrumentality] can sue is not so clear. Perhaps it could sue."127

The parties devoted extensive argument to the question of whether Upright's assignor could have sued. The plaintiff urged the analogy of such government corporations as the Reconstruction Finance Corporation and the United States Fleet Corporation, which, for sovereign immunity purposes, have been held to be distinct from the government that created them. ${ }^{128}$ Moreover, great emphasis was placed by plaintiff on Amtorg Trading Corp. v. United States. ${ }^{129}$ Amtorg, a New York corporation used by the Russians as their state-trading agency in the United States, appealed to the Customs Court from a Treasury Department ruling imposing an anti-dump-

125. 89 U.S. (22 Wall.) 99 (1875)

126. 13 App. Div. 2d at 39, 213 N.Y.S.2d at 421 (footnote of the court).

127. Id. at 41, 213 N.Y.S.2d at 423 . (Emphasis added.)

128. RFC v. Menihan Corp., 312 U.S. 81 (1941); Sloan Shipyards v. United States Fleet Corp., 258 U.S. 549 (1922).

129. 71 F.2d 524 (C.C.P.A. 1934). 
ing duty on products imported by it. The Government moved to dismiss the appeal on the ground that Amtorg could not sue in this country because it was an agency of the then unrecognized Soviet government. The motion was denied on the ground that Amtorg was a New York corporation; Amtorg also won on the merits. ${ }^{130}$ The Court of Customs and Patent Appeals reversed, but specifically ruled that Amtorg had capacity to sue. Incorporated under the laws of New York, it was, so far as the court had notice, "in all things, complying with the laws of the State of New York. It was, therefore, a citizen of that state, invested with the right to sue and be sued in the courts of the country. ... [It was] in all legal aspects, a citizen of the state of New York."131

Although the Amtorg case was extensively discussed in both briefs, the appellate division did not even mention it. ${ }^{132}$ By citing United States $v$. Insurance Cos., Justice Breitel was able to go further than Amtorg would have permitted him to venture. In the Insurance Cos. case, the plaintiff insurance companies, created by the Georgia legislature while Georgia was a member of the Confederacy, brought suit under the Captured and Abandoned Property Act ${ }^{133}$ to recover property seized during the Civil War. The United States argued that because they were created by the legislature of an insurgent state, the plaintiffs had no legal existence. The Supreme Court disagreed; applying a de facto test, it stated that acts contrary to the Constitution or the existence of the Union were invalid, but "no good reason can be assigned why all their other enactments, not forbidden by the Constitution, should not have the force which the law generally accords to the action of de facto public officers."134 Judged according to that standard, the enactments that had created the plaintiff corporations were valid.

The distinction between Amtorg and Insurance Cos. is obvious. While the court could rely on the fact that Amtorg was a New York corporation validly incorporated in a sister jurisdiction the legitimacy of whose government was unquestioned, in Insurance Cos. no such reliance was possible. In that case, the Court, viewing the problem from a broad perspective of policy, held that corporations created by a de facto government that had been in armed revolt against the United States possessed the capacity to sue. In light of the limitations that plaintiff had imposed on his argument by relying principally on Amtorg, Justice Breitel's citation of United States v. Insurance Cos. seems all the more striking.

130. Id. at 529,531 .

131. Id. at 528-29; accord, The Maret, 145 F.2d 431, 439 (3d Cir. 1944) (action by Amtorg as agent for agency of unrecognized Estonian government).

132. Justice Streit had rejected Amtorg as an analogy because in that case the unrecognized government owned the stock of the corporate plaintiff, while in Upright the corporation was alleged to be an "instrumentality" of the East German government. Justice Breitel regarded this as a distinction without a difference.

133. Ch. 120, 12 Stat. 820 (1863).

134. 89 U.S. (22 Wall.) at 101. 
However, if Justice Breitel's stress on Insurance Cos. emphasizes the link between Upright and the de factoism of the post-Civil War decisions, it conflicts with his expression of the rule that unrecognized governments can not sue. If "jural status" is the crucial factor, and if suit by a corporation created by an unrecognized government is permitted, would not the government itself thereby acquire "jural status"? From a viewpoint attentive to such "status," the existence of an unrecognized government as well as the power to create a corporate entity seem impliedly to receive "recognition" by allowing that entity to sue; this is especially true with respect to countries in which economic activities, particularly foreign trade, are directed by the state. On the other hand, Justice Breitel properly evinced no concern for "jural status" in noting that the acts of the East German government would be given effect to the extent that they affected the parties in Upright. It seems clear that the concept is of no real value in distinguishing, for the purpose of determining who may sue, a corporation from the government that created it. "Jural status" should therefore be excised completely from the thought and rhetoric of the courts in their attempts to resolve problems created by the impact on private rights of diplomatic nonrecognition.

Justice Breitel generated much more difficulty, however, by reiterating the Cibrario rule and simultaneously implying a possible exception for corporations. ${ }^{135}$ Although courts have often drawn a distinction between governments and corporations created by them when dealing with problems of sovereign immunity, ${ }^{138}$ any rule based on such a distinction seems too susceptible of manipulation to be of value. ${ }^{137}$ Surely it would not be difficult for a state to create a controlled entity, formally and apparently distinct from itself, that could bring suit under the suggested exception to the rule prohibiting suit by an unrecognized government. To create a corporate exception might at least superficially avoid eroding the rule while retaining sufficient latitude to permit suit on causes of action arising from transactions not

135. Such an exception has been suggested by Franck, The Courts, The State Department and National Policy: A Criterion for Judicial Abdication, 44 MiNN L. REv. 1101, 1111 (1960): "The courts' understandable reluctance to undermine the position of the United States as regards the legal status of a foreign political entity has not, however, precluded them from enabling these entities to carry on commercial and other 'non-sovereign' functions in this country." Franck cited Amtorg and Russian Volunteer Fleet v. United States, 282 U.S. 481 (1931), and added: "note that the relationship between the agency and the unrecognized government must not be such as to preclude the court from finding a separate corporate personality." Franck, supra at 1111 n.43. It seems, however, that since Amtorg rested on the fact that a New York corporation was the plaintiff, and because Russian Volunteer Fleet should also be limited to its peculiar facts, these cases do not establish a true "corporate exception."

136. E.g. United States v. Deutsches Kalisyndikat Gesellschaft, 31 F.2d 199 (S.D.N.Y. 1929); see RESTATEMENT, FOREIGN RELATIONS LAW OF THE UN1TED STATES $\S 53$, comment $d$ (Tent. Draft No. 2, 1958); Note, The Jurisdictional Immunity of Foreign Sovereigns, 63 YALE L.J. 1148, 1152-55 (1954). Contra, In re Investigation of World Arrangements, 13 F.R.D. 280 (D.D.C. 1952).

137. See Mexico v. Hoffman, 324 U.S. 30, $39-40$ (1945) (Frankfurter, J., concurring) (a state may, without great difficulty, create a variety of entities that resemble corporations but retain immunity). See also Note, 63 YALE L.J. 1148, 1153-54 (1954). 
affirmatively prohibited, such as the one in Upright. However, this exception to the Cibrario rule is inconsistent with the Cibrario decision; the opportunities for exploitation of the exception are so obvious as to raise substantial doubt that the Cibrario rule could coexist with it.

\section{CONCLUSION}

The suggested corporate exception does not provide a satisfactory alternative to the choices that are presently open to the courts: a realistic de factoism that can be used to limit the Cibrario rule, or a totally unnecessary dependence on distorted policy considerations.

Both Justice Breitel's de factoism in Upright (and the precedents for its application) and Justice Steuer's quite different views are relevant to this problem of choice. In his concurring opinion in Upright, Justice Steter stated:

As pointed out in the learned majority opinion, an unrecognized government lacks the capacity to sue. So does a branch or arm of that government, whether it be a corporation or any other entity. Concededly also, there is an infinite variety of relationship between governments and their corporate creations. By a branch of the government is meant an entity that performs governmental functions acting in its particular sphere as the alter ego of the government. Whether a particular corporation falls into that classification is a political rather than a juridical question, and the determination of the State Department on that question is conclusive. ${ }^{138}$

These views are consistent with the ill-advised Cibrario decision, but if the courts permit the State Department to determine whether a particular plaintiff is an agency of an unrecognized government they will be depending on the State Department unnecessarily. Justice Steuer's opinion bears an unfortunate resemblance to the dicta in the "Baltic ship" cases, dicta that it would be inappropriate to extend to matters of private right. More expressive of the proper judicial approach is Justice Breitel's statement that the issues of "jural status of the East German corporation ... or even of its capacity to sue in our courts . . . are issues to be resolved by reference to the actual facts," unless the "contemplated juridical consequences" of such "facts" are "inimical" to public policy. ${ }^{130}$

De factoism furnishes a rationale for intelligent resolution of the problem of the unrecognized government as plaintiff. Although it seems clear that conflicting policies can be inferred from nonrecognition of a government and the simultaneous legality of trade with it, courts traditionally measure conflicting policies, and they often fill gaps between policies that may compete without colliding. The de facto principle, with its sensitivity to policy, 
supplies a sound basis for measuring the policies relevant to the problem of the unrecognized government as party plaintiff, and it furnishes a rational basis for decision.

Justice Breitel's opinion in Upright indicates that in nonrecognition cases involving private transactions the policies to be given weight in determining whether an unrecognized government can bring suit are those derived from a consideration of the transactions themselves and not merely those flowing from the single fact of nonrecognition. When the de facto principle is employed, these policies assume more accurate proportions. ${ }^{140}$ In this connection, Professor Jaffe's words are apposite:

[U]nless the court is to be a mere weathercock of foreign policy, it must value the various types of international relations and sanctions, and their bearing on the administration of justice. War presents the clearest case. Intercourse of every sort is interdicted. To give comfort to the enemy is treason. Very probably the economic blockade, with its avowed object of isolating the assailed state, would be assimilated to war. Suits by either the state or its citizens would be denied. On the other hand, nonrecognition and severance of relations have not ordinarily been accompanied with the suppression of commercial intercourse, which carries a suggestion that the quarrel is one to be left to the devices of diplomacy and state action, and that the ordinary currents of international intercourse may flow on as well as they may..$^{141}$

Viewed in this perspective, the legality of the transaction on which suit is brought suggests a solution to the problem of whether suit should be permitted. If trade with an unrecognized government is not proscribed, suit should not be barred on the transactions constituting that trade. The legality of trade indicates that the basis of the Cibrario decision-the supposed need to deny funds to the unrecognized goverument-is totally absent from the case before the court.

Admittedly, the effect of diplomatic nonrecognition would be diluted by permitting an unrecognized government to sue. However, the executive policy underlying nonrecognition would not be impaired were a court to entertain suit on a lawful transaction by an entity created by an unrecognized government, or by that government itself. There is little validity to the contention that by permitting suit the courts would be "recognizing" the government, or its "jural status."142 A similar argument has been made and effectively answered with respect to choice of law problems:

140. See Dickinson, Recognition Cases 1925-1930, 25 Ax. J. INT'I L. 214, 237 (1931): "Experience indicates that 'an inversion of the exception of public order' is not required, but reference may be safely made to conditions prevailing or to laws in force under an unrecognized $d e$ facto government in the usual conflicts of laws way, and that the residuary judicial power to reject a reference on the ground that it would be inconsistent with the policy or public order of the forum is adequate to meet all emergencies likely to arise."

141. JAFFE, op. cit. supra note 98 , at 149.

142. The trade from which the suit would arise should not be considered as leading 
[T] he argument that any judicial recognition of the effect of a foreign government's acts amounts to a recognition of that government itself ignores the valid distinction which can be drawn between recognizing that a government is capable of affecting through its acts certain legal relationships and that a government is entitled to represent and bind a State internationally. ${ }^{143}$

Although there is a difference between applying the law of another state and permitting it to appear as plaintiff in the forum, it seems that the distinction is one of degree, not of kind, so far as "recognition" of a state by the courts of the forum is concerned.

In addition to the distinction that may be drawn between a government as a subject of international law and as a source of law within its territorial jurisdiction, a distinction may also be made between a government appearing as the representative of the nation it purports to govern and as a party to a commercial transaction. Use of the de facto principle requires the courts to take notice only of factual circumstances. This is not to say that the courts should make independent determinations of which of several rival claimants is the legitimate government of a country. In any case in which such a finding is required, the courts should properly defer to the State Department. ${ }^{144}$ However,

to "implied recognition." See Restatement, Foreign Relations LaW of the United STATĖs \& 9, comment $c$ (Tent. Draft No. 4, 1960):

Some types of associations with an unrecognized entity or regime are not customarily regarded as implying recognition. ... Practice of states indicates that the following types of association do not support an implication of an intention to recognize ...

(3) Permitting trade to continue or to be resumed, even such extensive trade in heavy capital goods as went on between business organizations in the United States and the USSR for many years prior to U.S. recognition.

The Restatement defines "recognition" itself as "an act by which a state commits itself to treat an entity as a state, or to treat a regime as the government of a state, for purposes of international relations." Id. \& 1(1). (Emphasis added.) Note also that a "state" may "recognize" only through a "person held out to the entity or regime to have authority to represent the state in the conduct of its foreign relations . . . "Id. \& $11(1)$. A court would hardly fit this description.

'143. Stevenson, Effect of Recognition on the Application of Private International Law Norms, 51 CoLUM. L. REv. 710, 727 (1951); see JAFFE, op. cit. supra note 98, at 167-68; cf. Restatement, Foreign Relations Law of tBe United States $\S 11(1)$, comment $b$ (Tent. Draft No. 4, 1960) :

Decisions by courts in the United States to the effect that unrecognized regimes

have certain powers to act within the territory controlled by them [to the lim-

ited extent to which such powers were acknowledged in Salimoff v. Standard

Oil Co., 262 N.Y. 220, 186 N.E. 679 (1933), discussed in text accompanying notes $55-60$ supra] ... do not constitute recognition of such regimes.

It should be noted, however, that immediately after the statement quoted in text Stevenson added: "Nor need there be any fear of embarrassing the executive in the conduct of foreign policy by giving effect to such acts, since if the executive desires that the unrecognized government's acts be treated as nullities, an express certification to that effect will be binding on the courts." Stevenson, supra at 727-28. The discussion from which these excerpts are taken concerns only the effect that American courts will give to confiscatory acts under the "act of state doctrine." In analyzing the effect of nonrecognition on cases involving the "act of state doctrine," Stevenson observed that "any attempt to superimpose on the normal private international law norms, as limited by the public policy of the forum, restrictive principles applicable to unrecognized governments can only hinder courts in the just resolution of controversies between private litigants." Id. at 730 .

144. Cf. Kennett v. Chambers, 55 U.S. (14 How.) 38 (1852) (independence of 
apart from this essential limitation, there is no reason why a court may not give effect to the undisputed existence of a government that rules a particular geographic area. Employment of the de facto principle in such a case bypasses such conceptual and political problems as "recognition" and "sovereignty." If a court applies to a transaction a rule of law emanating from an unrecognized government, it is applying it only because it is a rule in force at a particular place and time. It does so without acknowledging or being concerned with the legitimacy of any government as a source of law or as the representative of the nation it claims to rule. The problem of permissible plaintiffs deserves a similarly simple solution: a plaintiff should be permitted to sue because it exists as a matter of fact, and not because the court accepts it as a government and thereby accords it implicit "recognition." Application of the law of an unrecognized country may prevent a distortion of rights and obligations that should properly be determined by that law according to usual choice of law rules. To permit suit by an entity of an unrecognized government or by the government itself may prevent distortion of the plaintiff's rights, which is effected by denying it a forum in which its rights can be adjudicated. ${ }^{145}$

territory that had revolted); Rose v. Himely, 8 U.S. (4 Cranch) 241, 272 (1808) (same). But cf. Consul of Spain v. The Conception, 6 Fed. Cas. 359, 360 (No. 3137) (C.C.S.C. 1819 ) (dictum), rev'd on other grounds, 19 U.S. (6 Wheat.) 235 (1821). In Bank of China v. Wells Fargo Bank \& Union Trust Co., 92 F. Supp. 920 (N.D. Ca1. 1950), appeal dismissed, $190 \mathrm{~F} .2 \mathrm{~d} 1010$ (9th Cir. 1951), judgment entered, $104 \mathrm{~F}$. Supp. 59, 66 (N.D. Cal. 1952), modified, 209 F.2d 467 (9th Cir. 1953), appointees of the Chinese Communist government sued to recover American deposits of the Bank of China, the majority of the stock of which was state-owned. After appointees of the Nationalist government intervened, the plaintiffs moved for summary judgment, and intervenors moved to dismiss the complaint or to substitute their attorneys as of record. The court denied all the motions without prejudice and adjourned the trial sine die; although the Nationalist directors were scattered and their authority was doubtful, the United States had adopted an affirmatively hostile policy toward the Chinese mainland regime and the court did not wish to aid that regime.

Appeal was dismissed and the case remanded so that the district court could "re-examine the case in the light of changing world conditions and such additional evidence as may be made available to it by the respective parties." 190 F.2d at 1012 . On remand, judgment was entered for the Nationalist appointees. The court asserted that although diplomatic nonrecognition could not impose on the courts the obligation to disregard totally all unrecognized governments and their acts, national policy toward the People's Republic of China was so definitively established that it should be followed. The court stated: "It is not a proper function of a domestic court of the United States to attempt to judge which government best represents the interests of the Chinese State in the Bank of China. In this situation, the Court should justly accept, as the representative of the Chinese State, that government which our executive deems best able to further the mutual interests of China and the United States." $104 \mathrm{~F}$. Supp. at 66.

145. This distortion may not be competely eliminated when an unrecognized government receives diplomatic recognition. See Union of Soviet Socialist Republics v. National City Bank, 41 F. Supp. 353 (S.D.N.Y. 1941). In that case the Russian government attempted to recover funds that had been deposited with the defendant pursuant to its agreement with the same Cibrario whom it had unsuccessfully sought to sue for an accounting in the Cibrario case. The court rendered judgment for the defendant, holding that the period of nonrecognition had not tolled the applicable statute of limitations because the representatives in this country of the exiled Provisional government could have brought suit on behalf of "the Russian State." Accord, United States v. Guaranty Trust Co., 304 U.S. 126 (1937), on which the court relied.

The court regarded the continued running of the statute of limitations as a proper consequence of nonrecognition: 
Further, it can not meaningfully be argued that although use of the de facto principle would not formally involve judicial "recognition" of the unrecoguized government, it could impair the effectiveness and coherence of our foreign policy. Such an argument assumes too much. The very diversity of diplomatic and trade policies that creates the problem indicates that "foreign policy" is not monolithic and absolute; it is much less unified. Put another way, there is a difference between the political level at which the policy of nonrecognition operates and the private level at which commercial intercourse is conducted. When the two are not uniformly regnlated, their diversity should be allowed to continue. It may happen, as in the case of relations with the People's Republic of China, that trade with the unrecognized country is prohibited. When it is not prohibited, however, a fear that courts will erode national policy by allowing suits on transactions entered into as part of permitted trade is unfounded. The legality of the transactions is sufficiently expressive of national policy.

To reach a reasonable solution of the problem of the unrecognized government as plaintiff, the courts must employ a more considered method. It is necessary that they fashion an adjustment in their relations with the State Department. In other circumstances, Congress has established a procedure for State Department certification to the courts of essential and policydictated information that will necessarily influence, if not control, the result. ${ }^{140}$ But no legislation exists to guide the courts in resolving the problem discussed here; it seems clear, moreover, that no legislation is necessary.

The de facto principle can be used by the courts to establish a balance between their independence and the demands of a foreign policy. By using it, they can also restrain the judicial proclivity for unthinking deference to what the courts consider to be, or are told is, national policy. Moreover, the adjustments that must be made are not always too delicate for the courts to fashion. If such an approach is adopted, it may no longer be necessary to ask why a plaintiff should be barred from bringing suit on a contract merely because an official of the executive branch asserts that plaintiffs "of

One of the results of non-recognition of a foreign government is its incapacity to bring suit in our courts. Were it decided that during that period of non-recognition the statute of limitations was merely tolled and did not run, one of the most effective sanctions of non-recognition would lose most of its value. It always rests within the power of a foreign government to secure recognition by complying with the requests of our government. If, under such circumstances, the foreign government chooses to remain unrecognized, it must take with it the consequences in the form of incapacity to sue in our courts which may include loss of substantive rights.

$41 \mathrm{~F}$. Supp. at 355.

146. See 48 Stat. 184 (1933), as amended, 12 U.S.C. \& 632 (1958), which provides that payment to a representative of a foreign state of property held by a Federal Reserve Bank for the account of that state shall be conclusively presumed to be lawful if the state is recognized and if the Secretary of State certifies to the Bank that the representative is authorized to receive the property. 
this kind" sometimes do business with persons "who do not have the best reputations."147

This article has been directed to a highly limited problem; no attempt has been made to link the suggested solution to a general criterion for determining the areas in which the State Department and the courts should predominate. The international problems that create possibilities of conflict between the executive and judicial institutions are so variable, as are the contexts in which the conflicts may arise, that formulation of general criteria neither avoids nor eases the task of contriving a balanced relationship between executive and judiciary. ${ }^{148}$ But the courts do strike the balance, albeit clumsily, in meeting problems other than those created by nonrecognition. ${ }^{149}$ The employment of de factoism provides a method whereby the courts are encouraged, if not enabled, to decide thoughtfully which unrecognized governments can sue, and under what circumstances. ${ }^{150}$ There is no reason why Lord Eldon need have the last word.

147. See the text of the reply sent by the United States Mission to West Berlin in response to defendant's request for information about the plaintiff's assignor, note 7 istupra.

148. See Franck, supra note 135 passim, urging that the courts need not defer to the State Department "in those cases in which there is at stake no matter of international law substantially affecting the national interest" and attempting to apply a "pragmatic technique" to some of these problems. Plainly, as Franck recognized, "not a rule, but a niethod" is needed. Id. at 1104, 1123. See also Restatement, Foreign Relations Law of the UnITEd States $\& 59$, comment $b$ (Tent. Draft No. 2, 1958), which expresses the view that State Department suggestions concerning sovereign immunity should be considered conclusive "only with respect to such statements as are within the exclusive responsibility of the Executive Branch of the Government."

149. Thus, in cases involving questions of sovereign inmunity, the courts are not foreclosed from determining that immunity has been waived, Mexico v. Schmuck, 293 N.Y. 264, 56 N.E.2d 577 (1944), or from determining whether a defendant is acting as agent of a sovereign or as its trustee, Frazier v. Hanover Bank, 119 N.Y.S.2d 319 (Sup. Ct.), aff'd mem., 281 App. Div. 861, 119 N.Y.S.2d 918 (1st Dep't 1953), or from determining that the defendant was not in possession of a vessel that it claimed was immune, Mexico v. Hoffman, 324 U.S. 30 (1945) ; cf. Banco de Espana v. Federal Reserve Bank, 114 F.2d 438 (2d Cir. 1940) (statement of Secretary of Treasury that United States derived good title to gold purchased from foreign bank not binding on court).

The excessive deference the courts have accorded the State Department in matters of sovereign immunity has often been the subject of comment. See, e.g., Drachsler, Some Observations on the Current Status of the Tate Letter, 54 AM. J. INT'L L. 790 (1960); Jessup, Has the Supreme Court Abdicated One of its Functions?, 40 AM. J. INT'L L. 168 (1946) ; Kuhn, The Extension of Sovereign Imminity to Government-Ovened Commercial Corporations, 39 Ax. J. InT'L L. 772 (1945).

150. The argument for use of de factoism as an alternative method of decision is buttressed not only by a survey of the decisions that express traditional law, but also by the formulation of the Restatement, which accurately reflects the reluctance of American courts to give effect to the acts of unrecognized governments, and the rigidity of their attitudes. American policy is stated to require, as a condition of American recognition of a foreign government, not only that it meet the minimun international law standard of effective control, Restatement, Foreign Redations Law of the United States $\S \S 6,7$ (Tent. Draft No. 4, 1960), but that it also be willing to fulfill the obligations of the state under "general international law and international agreements." Id. \& 8. In its own expression of traditional law, the Restatement adds that American courts refuse to go beyond the decision in Salimoff v. Standard Oil Co., 262 N.Y. 220, 186 N.E. 679 (1933), in giving effect to the acts of unrecognized governments. $\$ 8$, comment $a, \S 18$, comments $a-d$.

As to the problem of the unrecognized government as a party plaintiff, $\S 12$ provides as follows: 


\section{Rights of the State in the Absence of Recognition: General Rule}

An entity not recognized as a state but meeting the [minimum international law standard of effectiveness] or a state whose territory and population are under the control of a regime not recognized as its government, has the rights of a state under international law in relation to a non-recognizing state, although it may be precluded from exercising such a right if:

(a) The right in question is of such a nature that it can only be exercised by the government of the state; and

(b) The non-recognizing state refuses to treat the regime purporting to exercise the right as the government of the state.

Comment $c$ to this rule states that:

A state is not required by international law to accord other states access to its courts, as long as appropriate means are available for determining the rights of other states, such as diplomatic negotiations. Where a state is bound by international agreement to accord such access, however, or does so as a matter of general state policy or domestic law, the question arises whether such access should be accorded to unrecognized regimes. The rule stated in this section does not require access [citing as American authority, The Rogdai, 278 Fed. 294 (1920); The Penza, 277 Fed. 91 (1921); Russian Socialist Federated Soviet Republic v. Cibrario, 235 N.Y. 255, 139 N.E. 259 (1923)].

However, a de factoism alternative to the American judicial practice is suggested by the statement that the rule of $\$ 12$ "is, however, only permissive and there have been cases in which a non-recognizing state has allowed an unrecognized regime to be a plaintiff in its courts." $\S 12$, comment $c$. Cited as support for this statement are Représentation Commerciale de l'Ưnion des Républiques Socialistes Soviétiques en Turquie c. Levant Red Sea Coal Cy et autres Trib. Mixtes d'Egypte, March 29, 1933, 62 Journat DU Droit INTERNATIONAL 199 (1934) (Fr.) (Soviet government permitted to bring suit to enforce commercial transaction); Republic of the South Moluccas v. Netherlands New Guinen, [1954] Int'1 L. Rep. 48 (No. 549) (Neth.); "Exportchleb" Ltd. v. Goudeket, [19351937] Ann. Dig. 117 (No. 36) (Neth.) (assignee of unrecognized Soviet government could sue; dictum that Soviet government could itself sue). See note 85 supra.

In the South Moluccas case, the court held that the plaintiff, which in 1950 had proclaimed itself to be a sovereign state independent of the Republic of Indonesia, could maintain an action for an order preventing the Government of Netherlands New Guinea from transferring a vessel the title to which was alleged to be in the plaintiff. The "legal personality" of the plaintiff had been recognized by the Court of Appeal of Amsterdam in an earlier decision, Republic of South Moluccas v. Komnklijke Paketvaart Maatschappij, Jan. 8, 1951, [1951] Nederlandse Jurisprudentie (No. 129), and the court noted that it had been shown no "reliable data from which it would follow that the claimant has lost its legal personality since the previous judgments were given $\therefore$. [1954] Int'1 L. Rep. at 48-49 (No. 549). The earlier decision on which the District Court of The Hague relied is discussed in Bos, Le Premier Proces de la République des Molucques du Siud contre la S. A. Koninklijke Paketvaart Maatschappij, 80 JourNaL DU Drott International 286 (1953). 